\title{
Forecasting of Tourism Companies Before and During Covid-19
}

\author{
Asima Sarkar \\ Dept. of Management \& Business Administration, Aliah University, New Town, Kolkata \\ Action Area II, Plot No.IIA/27, Newtown, Kolkata, West Bengal 700156, India
}

\begin{tabular}{|c|c|}
\hline ARTICLE INFO & A B S T RACT \\
\hline $\begin{array}{l}\text { Keywords: } \\
\text { Forecasting, } \\
\text { Stock Market, } \\
\text { Neural Network, } \\
\text { GRU } \\
\text { Kata Kunci: } \\
\text { Peramalan, } \\
\text { Pasar Saham, } \\
\text { Neural Network, } \\
\text { GRU }\end{array}$ & $\begin{array}{l}\text { For about last two years, the whole world is suffering from a novel disease } \\
\text { i.e. Covid-19. When it was first diagnosed in China, even the giant health } \\
\text { agencies could not predict the severity and spread of this disease. Slowly, } \\
\text { when this novel corona virus had an outbreak the countries stopped all } \\
\text { kinds of communication be it interstate or intercountry and so the tourism } \\
\text { companies started facing huge loss due to lockdown in every single country. } \\
\text { In this paper, the stock prices of the multinational tourism companies } \\
\text { that operate in India, have been forecasted and using an online learning } \\
\text { algorithm known as Gated Recurrent Unit (GRU). As we know that predicting } \\
\text { stock prices is not an easy task to do, it requires extensive study of the stock } \\
\text { market and intervention of statistical and machine learning models. We } \\
\text { will try to spot whether the forecasting before pandemic is better than the } \\
\text { forecasting during the pandemic for each of the six leading multinational } \\
\text { tourism companies. }\end{array}$ \\
\hline
\end{tabular}

SARI PATI

Selama sekitar dua tahun terakhir, seluruh dunia menderita penyakit baru bernama Covid-19. Ketika pertama kali didiagnosis di China, lembaga kesehatan raksasa pun tidak dapat memprediksi tingkat keparahan dan penyebaran penyakit ini. Perlahan-lahan, ketika virus Korona baru ini mewabah, negara-negara menghentikan semua jenis komunikasi baik itu antarwilayah atau antarnegara, sehingga perusahaan-perusahaan pariwisata mulai mengalami kerugian besar karena penguncian di setiap negara. Dalam makalah ini, harga saham perusahaan pariwisata multinasional yang beroperasi di India, telah diramalkan menggunakan algoritma pembelajaran online yang dikenal sebagai Gated Recurrent Unit (GRU). Seperti yang kita ketahui bahwa memprediksi harga saham bukanlah tugas yang mudah untuk dilakukan, memerlukan studi ekstensif tentang pasar saham dan intervensi model statistik dan pembelajaran mesin. Kami akan mencoba melihat apakah prakiraan sebelum pandemi lebih baik daripada prakiraan selama pandemi untuk masing-masing enam perusahaan pariwisata multinasional terkemuka. 


\section{INTRODUCTION}

Stock prices are always an attractive area to focus on for the investors and the researchers. There are many factors that affect the stock market such as social movements, natural calamities, pandemics etc. Since the inception of the novel corona virus in China, the whole world is suffering not only from the disease but from a severe economic crisis. Except the ecommerce sites, almost all other industries have seen a great loss during this time. People had to lock themselves at their places and due to this, even grocery shops suffered losses. As people are unable to commute from one place to another due to lockdown and fear of being affected by Covid-19. During the Covid-19 period of time, the tourism companies all over the world faced a steep downfall in their business. Although there were increment of volatility of stock market during the Great Depression in the year 1993 and the Global Financial Crisis that held in the year 2008, it has been observed by (Baker, Bloom, Davis, Kost, Sammon, \& Viratyosin , 2020) that the highest among all such incidences, the volatility increment during Covid-19 is the highest that is about $0.5 \%{ }^{[1]}$. (Refenes, Zapranis \& Francis, 1994) applied machine learning models for the first time for predicting stock prices before that there was several statistical models for forecasting stock market data ${ }^{[2]}$. Since then, there were plethora of attempts to forecast the stock market using various machine learning models. Gao, (2020) reported that application of algorithms based on Artificial Intelligence (AI) are extremely powerful for forecasting stock prices [3]. (Jin, Li, Yu \& He, 2018), (Lorencin, AnCeli'c, Mrzljak \& Car, 2019) and (Lorencin, AnCeli'c, Mrzljak \& Car, 2020) tested the efficiency of AI models in the fields on science, technology and medicine [4], [5], [6]. (Jia, Huang, Pang, \& Zhao 2019) showed that for forecasting GREE stock price, bidirectional LSTM performed very well [7].

As we know that, even after the imposed lockdown was withdrawn, people were not comfortable to go to any destination and stay at hotels due to the fear of getting affected by Covid. Many hotel bookings were cancelled and hotels were used as the satellite centres for Covid-19patients with lesser severity. This resulted in a forced closing of operations by many tourism companies. (Chang, McAleer \& Ramos 2020) and (Ivanov, Webster, Stoilova \& Slobodskoy 2020) predicted the gravity of the impact of Covid-19 on the hospitality, travel and tourism industries all over the world [8], [9]. In this study, we have taken the leading multinational tourism companies for forecasting their stock prices before Pandemic and during the same using three machine learning algorithms. This paper used the stock process of MakemyTrip, Yatra, Thomascook, Flight Centre Travel Group Ltd., Mahindra Holidays and Resort India Ltd. and Expedia and predicted the future stock prices by using a Gated Recurrent Unit (GRU). We have tried to see whether the performance of these models are different in pre and during pandemic period.

\section{Related Works}

Lawrence (1995) reported that neural network models are compared with fundamental analysis and regression and the Efficient Market Hypothesis $(\mathrm{EMH})$ has been contrasted with the neural network models [10]. A hybrid of Autoregressive Integrated Moving Average (ARIMA) and an Artificial Neural Network (ANN), ARIMA-ANN is established for forecasting time series data by (Narendra Babu, \& Reddy, 2014) [11]. Hybrid Deep Learning models are some of the models that can forecast the stock market (Asiful, Hossain, Thulasiram, Bruce, \& Wang, 2018) [12]. (Zhang, Li, Ye, Li, \& Ngai, 2015) discuss the twitter sentiment and business network models and then predict the stock price movement [13]. (Wilson \& Sharda, 1994) also tried to compare the forecasting efficiency of different classical statistical models with neural network models for predicting firm bankruptcy and found the neural network models to perform better than other models [14]. Dow Jones Industrial Average, FTSE 100, Nikkei 225 and Taiwan Stock Exchange Capitalization Weighted Stock Index have been taken by (Hsieh, Hsiao \& Yeh, 2011) to study the efficiency of Integrated Wavelet transforms and RNN models and 
they proved that the forecasting done on some of the indexes gave significantly good result and could be used in real life to predict the movement of a stock [15]. RNN, CNN and LSTM models are compared by (Selvin, Vinayakumar, Gopalakrishnan, Menon, \& Soman, 2017). They showed that when the window size was fixed at 100 minutes with an overlap of 90 minutes information, CNN model performed better than other models taken in their study [16]. Using MLP and LSTM, 10 stocks traded on New York Stock Exchange were forecasted and it has been shown that LSTM model successfully predicted the future price of the stocks but it was unable to forecast the exact price whereas MLP gave a higher accuracy level than LSTM in all the aspects (Khare, Darekar, Gupta, \& Attar, 2017) [17]. (Zhuge, XU, \& Zhang, 2017) took Shanghai Stock Composite Index (SCI) and applied a two-part analytical model - emotional analysis and LSTM [18]. (Yang, Gong, \& Yang, 2017) forecasted SCI and SZSE Index using deep neural network model with an accuracy of $72.34 \%$ and 73.95\%. They also established that the combined models performed better in terms of relative error [19]. (Maas, Hannun, \& Ng, 2013) predicted stocks of some companies that are listed in NSE using
RNN, CNN and LSTM and they used sliding window approach. They found that CNN performed better in case of their dataset [20]. (Fotiadis, Polyzos , Huan 2021) studied the accuracy of two machine learning models- LSTM and Generalised Additive Model on the pretext of Covid-19 scenario for tourism industry. They predicted a downfall of tourist arrival ranging between $30.8 \%$ and $76.3 \%$ and this is really alarming [21]. From the literature survey, we have observed that comparison of machine learning models has been performed in many situations but the effect of Covid-19 on the tourism companies' stocks has not been considered on the forecasting accuracy of machine learning models.

\section{METHODS}

An Artificial Neural Network (ANN) has three layers (Jin, et. al., 2018) [4]:

i). Input Layer

ii). Hidden Layer

iii). Output layer.

Several nodes are present in the input layer and connected to the hidden layer through synapses in the Neural Network. Each of these synapses has an

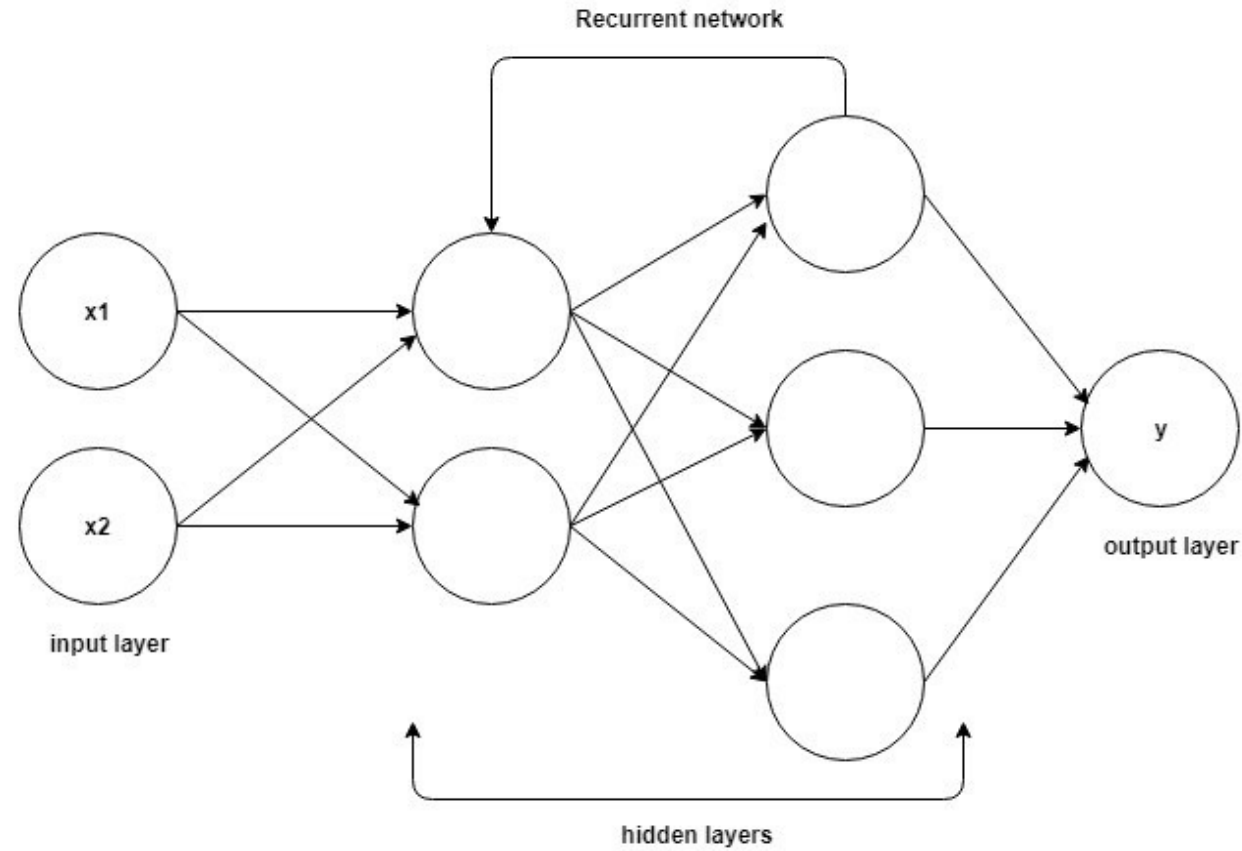

Figure 1. Architecture of Neural Network 
initial weight which is the coefficient of relationship between the input layer and the hidden layer. In the learning stage of a Neural Network, these weights are continuously adjusted till an optimal weight distribution is achieved.

After this, the hyperbolic tangent function (tanh) is applied by the hidden layer nodes. The tanh function sum of the weights of all the synapses is calculated to minimize the rate of error between the train and test data and we get the nodes. To optimize these values, a back-propagation process is applied which connects the output layer to the hidden layer and then takes out the optimal values of the nodes of the output layer. This process of back propagation will be repeated in the training set of data to make the prediction better and to minimize the error and after the optimal values are achieved, the training set is ready. Predicting future values based on the past sequence of observation can be done through the Recurrent Neural Network (RNN). But RNN cannot remember long term data so we use a Long Short-Term Memory which is very efficient in remembering the long-term data points. On the other hand, LSTM has a special feature of dropping all unnecessary information (Patterson, 2017) [22].
This is done by using the sigmoid layer. A new vector of all possible values from the input layer is created by using the tanh function.

Gated Recurrent Unit (GRU) is a variant of Recurrent Neural Network (RNN) which is similar to the LSTM (RNN) but unlike LSTM, GRU is comprised of only two gates and those are a reset gate and an update gate (Cho, Bart, Caglar, Dzmitry, Bougares, Schwenk, \& Bengio, 2014) [23]. Due to lesser number of gates, GRU computes faster than LSTM. Reset gate is used to decide the amount of past information to be forgotten whereas the update gate decides which information is to be discarded and which one is to be added. It cannot be said clearly whether GRU or LSTM is better but GRU is a time saver (Weiss, Goldberg \& Yahav, 2018) [24].

\section{RESULTS AND DISCUSSION}

Daily closing price of six leading multinational tourism companies from $01 / 08 / 2018$ to $31 / 05 / 2021$ has been taken in this study. The companies those are taken in this study are Makemytrip, Thomascook, Yatra, Flight Centre Travel, Mahindra Travel and Resort and Expedia. Data taken under this study have been downloaded from the website

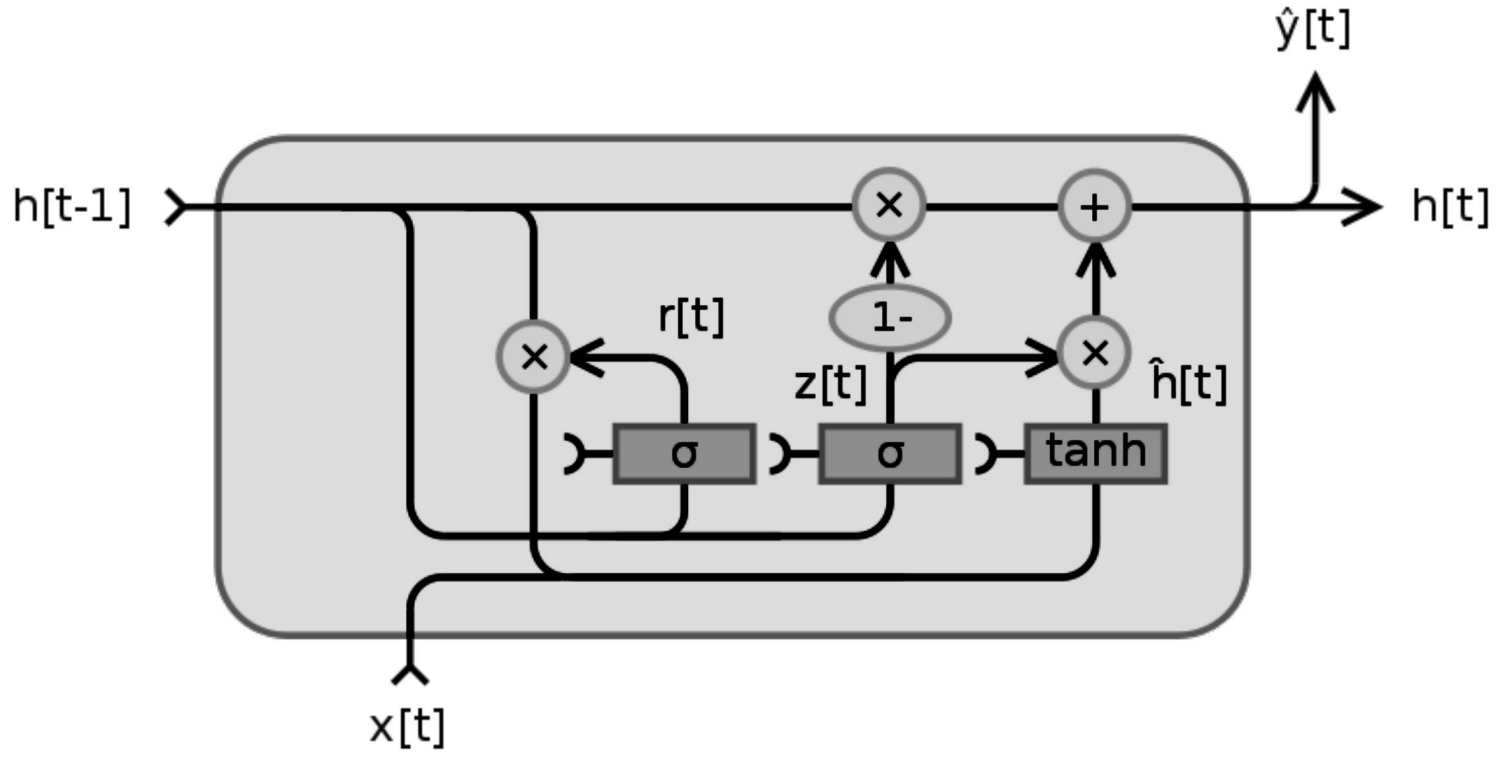

Figure 2. Architecture of Gated Recurrent Unit (GRU) 
https://in.finance.yahoo.com. As we know that the first case of Covid-19 was reported on 31.12.2019 (WHO report 2019), we have divided the whole dataset into two parts - Pre Covid-19 (from 01/08/2018 to 31/12/2019) and the During Covid-19 (from $01 / 01 / 2020$ to $31 / 05 / 2021$ ) periods. GRU at epoch 25 has been applied to the stock prices for both the periods and it is tried to compare the performance of these models for the pre and during Covid-19 periods.

Table 1. Forecasting plots of GRU at epoch 25

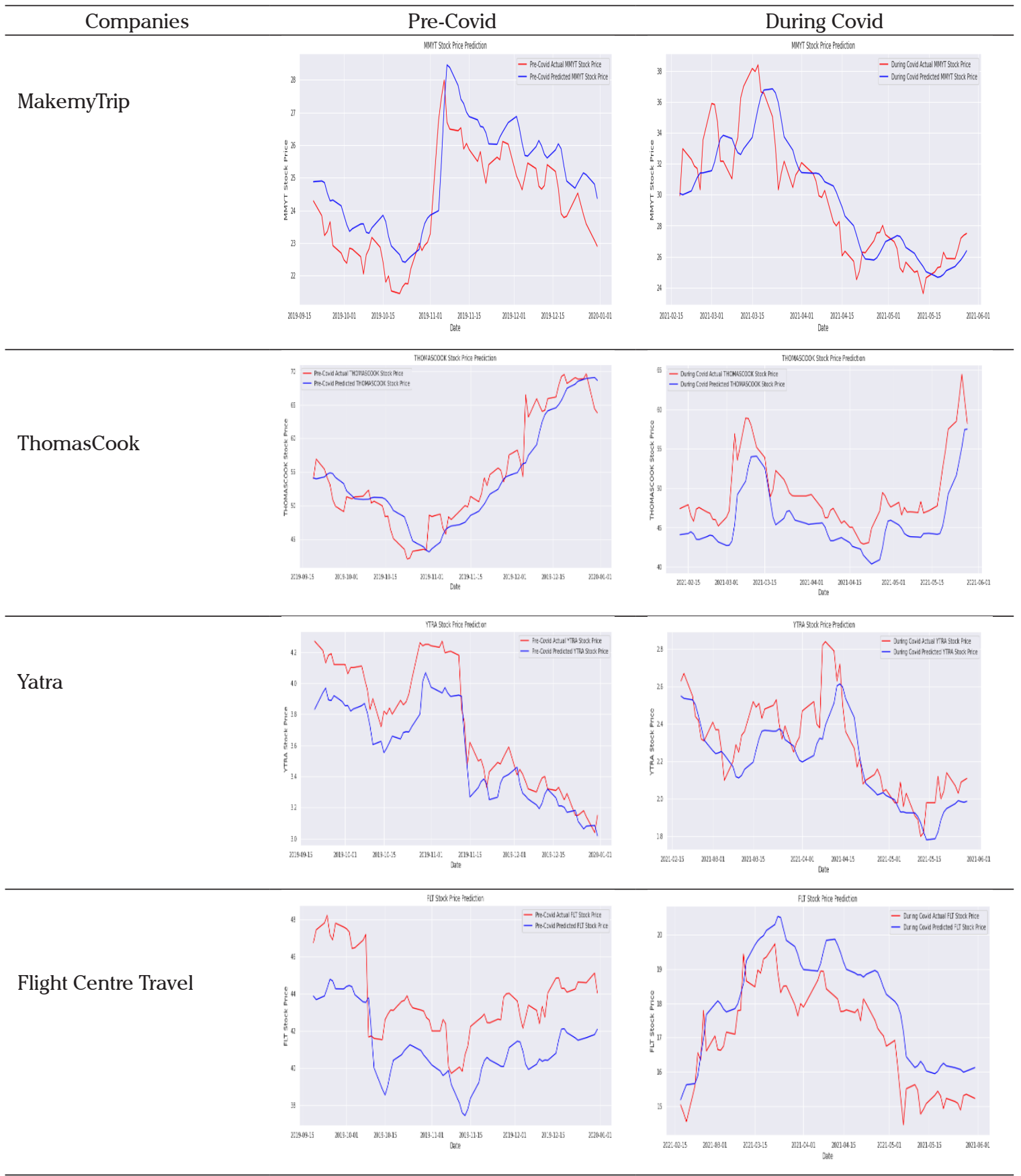




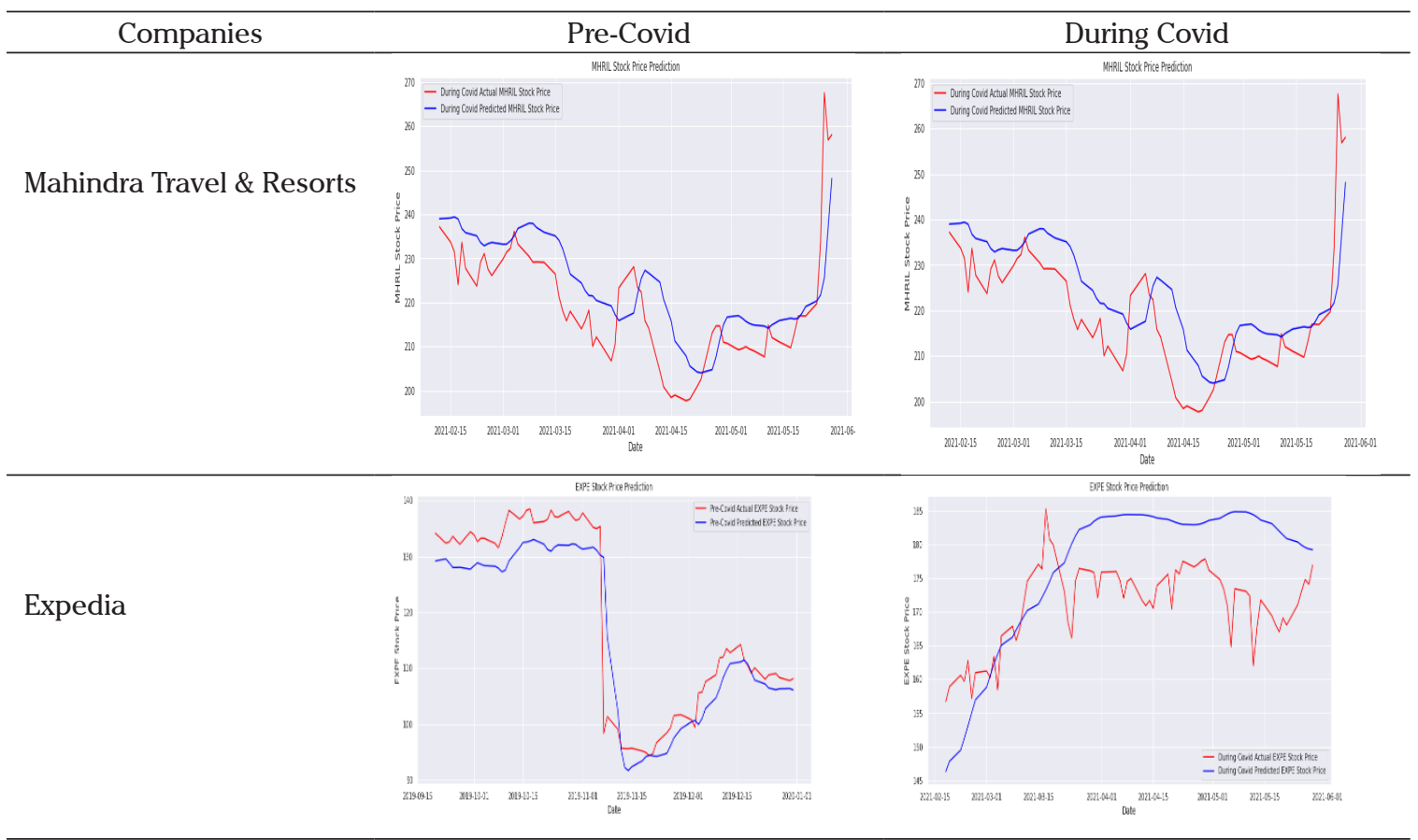

From the above table it can be observed that, for all the stocks GRU is slightly performing better in the Pre-Covid-19 period which is again supported by the metric Mean Absolute Percentage Error (MAPE) in Table 2. Just by observing the plots, it's not easy to conclude about the efficiency of the forecasting for the different time periods, so MAPE has been calculated for both the time periods for all the stocks.
From Table 2, it is evident that for all the companies MAPE is lower in Pre-Covid-19 period. So, in PreCovid-19 period forecasting efficiency of GRU is better for all the stock prices.

\section{MANAGERIAL IMPLICATIONS}

This study will help the financial managers to decide on the effectiveness of machine learning models in forecasting future prices of a stock and hence can

Table 2. Mean Absolute Percentage Error (MAPE) of GRU for Pre and Duding Covid-19 period

\begin{tabular}{llr}
\hline Companies & Model & MAPE \\
\hline \multirow{2}{*}{ MakemyTrip } & Pre-Covid-19 & $4.374047^{*}$ \\
\cline { 2 - 3 } ThomasCook & During Covid-19 & 5.350936 \\
\hline \multirow{2}{*}{ Yatra } & Pre-Covid-19 & $4.419034^{*}$ \\
\cline { 2 - 3 } & During Covid-19 & 7.399156 \\
\hline \multirow{2}{*}{ Flight Centre Travel } & Pre-Covid-19 & $4.566534^{*}$ \\
\cline { 2 - 3 } & During Covid-19 & 5.052627 \\
\hline \multirow{3}{*}{ Mahindra Travel \& Resort } & Pre-Covid-19 & $6.041635^{*}$ \\
\cline { 2 - 3 } Expedia & During Covid-19 & 6.332537 \\
\cline { 2 - 3 } & Pre-Covid-19 & $3.457198^{*}$ \\
\hline
\end{tabular}


apply the same knowledge to give better profit to the financial companies.

\section{CONCLUSION AND FUTURE SCOPE}

This paper studied the efficiency of the machine learning GRU for epoch 25 for two time periods for six leading tourism companies. In this paper, it is established that machine learning models are quite efficient in case of predicting stock prices. This study reports that for all the six companies, GRU performed significantly well in case of Pre-Covid-19 period which can be established by observing the
MAPE values of GRU model for each of the companies. This may be due to the higher volatility in the market due to Covid-19 news and the economic conditions of the tourism companies. It can be concluded that the leading tourism companies suffered from uncertainty and a huge financial loss in their business. In future, we may further study their internal financial data instead of stock prices to conclude about their financial status. We may also try to employ different statistical and machine learning models for the analysis and compare their accuracy.

\section{REFERENCES}

Asiful, M., Hossain, R., K., Thulasiram, R., Bruce, N. D. B., Wang, Y., (2018). Hybrid Deep Learning Model for Stock Price Prediction. 2018 IEEE Symposium Series on Computational Intelligence (SSCI).

Baker, S. R., Bloom, N., Davis, S. J., Kost, K., Sammon, M., \& Viratyosin, T. (2020). The Unprecedented Stock Market Reaction to COVID-19, Review Asset Pricing Studies, 10(4), 742ñ758,

Chang, C. L., McAleer, M., \& Ramos, V. (2020). A charter for sustainable tourism after COVID-19. Sustainability, 12(9), 3671.

Cho, K., Bart, V. M., Caglar, G., Dzmitry, B., Bougares, F., Schwenk, H., and Bengio, Y., (2014). Learning Phrase Representations using RNN EncoderñDecoder for Statistical Machine Translation, Conference on Empirical Methods in Natural Language Processing (EMNLP). ACL, Doha, 1724-1734.

Fotiadis, A., Polyzos , \& S., Huan T. C., (2021). The good, the bad and the ugly on COVID-19 tourism recovery, Annals of Tourism Research, 87, 103117

Gao, Z. (2020). e application of artificial intelligence in stock investment, Journal of Physics: Conference Series, 1453, Article ID 012069

Hsieh, T., Hsiao, H., Yeh, W., (2011), Forecasting Stock Markets Using Wavelet Transforms and Recurrent Neural Networks: An Integrated System Based on Artificial Bee Colony Algorithm, Applied Soft Computing, 11(2), 2510-2525.

Ivanov, S., Webster, C., Stoilova, E., \& Slobodskoy, D. (2020). Biosecurity, automation technologies and economic resilience of travel, tourism and hospitality companies. DOI:10.31235/osf.io/2hx6f

Jia, M., Huang, J., Pang, L., \& Zhao, Q. (2019). Analysis and research on stock price of LSTM and bidirectional LSTM neural network, Proceedings of the 3rd International Conference on Computer Engineering, Information Science \& Application Technology (ICCIA 2019), Chongqing, China, May 2019.

Jin, L., Li, S., Yu, J., \& He, J. (2018). Robot manipulator control using neural networks: a survey, Neuro Computing, 285. 23 ñ34.

Khare, K., Darekar, O., Gupta, P., and Attar, A. Z. (2017). Short Term Stock Price Prediction Using Deep Learning. IEEE International Conference on Recent Trends in Electronics, Information \& Communication Technology (RTEICT). IEEE, Bangalore, 482-486.

Lawrence, R. (1995). Using Neural Networks to Forecast Stock Market Prices. Neural Networks in the Capital Markets, John Wiley and Sons, chapter 10, 149ñ162. 
Lorencin, I., AnCeli¥c, N., Mrzljak, V., \& Car, Z. (2019). Genetic algorithm approach to design of multi-layer perceptron for combined cycle power plant electrical power output estimation, Energies, 12(22), 4352.

Lorencin, I., AnCeliłc, N., Spanjol, J., \& Car, Z. (2020). Using multilayer perceptron with Laplacian edge detector for bladder cancer diagnosis, Artificial Intelligence in Medicine, 102, Article ID 101746.

Maas, A. L., Hannun, A. Y., \& Ng, A. Y. (2013). Rectifier nonlinearities improve neural network acoustic models. In Proc. ICML, $30(1), 3$.

Narendra Babu, C. and Reddy, E. B., (2014). A moving-average filter-based hybrid ARIMA-ANN model for forecasting time series data. Applied Soft Computing, 23, 27-38.

Patterson, J., (2017). Deep Learning: A Practitionerís Approach, OíReilly Media. ISBN: 9781491914250.

Refenes, A. N., Zapranis, A., and Francis, G. (1994). Stock performance modeling using neural networks: a comparative study with regression models, Neural Networks, 7(2), 375-388.

Selvin, S., Vinayakumar, R., Gopalakrishnan, E., Menon, V., and Soman, K. (2017). Stock price prediction using LSTM, RNN and CNN-sliding window model. International Conference on Advances in Computing, Communications and Informatics (ICACCI). IEEE, Udupi, 1643-1647.

Weiss, G., Goldberg, Y., and Yahav, E. (2018) On the Practical Computational Power of Finite Precision RNNs for Language Recognition, 56th Annual Meeting of the Association for Computational Linguistics. ACL, Melbourne, 740-745.

Wilson R. L., Sharda R., (1994). Bankruptcy Prediction Using Neural Networks, Decision support systems, 11(5), 545-557.

Yang, B., Gong, Z., and Yang, W. (2017). Stock Market Index Prediction Using Deep Neural Network Ensemble. 36th Chinese Control Conference. IEEE, Dalian, 3882-3887.

Zhang, W., Li, C., Ye, Y., Li, W., and Ngai, E. W. T., (2015). Dynamic Business Network Analysis for Correlated Stock Price Movement Prediction, IEEE Intelligent Systems, 30(2), 26-33.

Zhuge, Q., XU, L., and Zhang, G. (2017). LSTM Neural Network with Emotional Analysis for prediction of stock price, Engineering Letters, 25(2), 167-175. 